\title{
FOTODEGRADASI FENOL MENGGUNAKAN KOMPOSIT Ag/ZnO YANG DISINTESIS DENGAN METODE KOPRESIPITASI
}

\author{
Ni Putu Diantariani* dan Ida Ayu Gede Widihati \\ Program Studi Kimia FMIPA Universitas Udayana, Bukit Jimbaran, Badung, Bali 80361 \\ "E-mail: putu_diantariani@unud.ac.id
}

\begin{abstract}
ABSTRAK
Penelitian ini mengenai fotodegradasi fenol dengan menggunakan komposit $\mathrm{Ag} / \mathrm{ZnO}$ yang disintesis dengan metode kopresipitasi. Penelitian yang dilakukan meliputi sintesis komposit $\mathrm{Ag} / \mathrm{ZnO}$, penentuan kondisi optimum fotodegradasi, penentuan efektivitas dan laju fotodegradasi fenol dengan menggunakan fotokatalis komposit $\mathrm{Ag} / \mathrm{ZnO}$. Hasil penelitian menunjukkan bahwa metode kopresipitasi dapat menghasilkan komposit $\mathrm{Ag} / \mathrm{ZnO}$ dengan persentase $\mathrm{Ag}$ dalam komposit sebesar 3,4\%. Komposit $\mathrm{Ag} / \mathrm{ZnO}$ yang dihasilkan mempunyai aktivitas fotokatalitik yang tinggi. Kondisi optimum proses fotodegradasi fenol dengan komposit $\mathrm{Ag} / \mathrm{ZnO}$ yaitu menggunakan komposit $\mathrm{Ag} / \mathrm{ZnO}$ sebanyak $50 \mathrm{mg}$, $\mathrm{pH}$ larutan fenol 7 dan diradiasi dengan sinar UV selama 8 jam. Efektivitas fotodegradasi fenol rata-rata dengan fotokatalis komposit $\mathrm{Ag} / \mathrm{ZnO}$ pada kondisi optimum sebesar $(82,88 \pm 0,41) \%$.
\end{abstract}

Kata kunci : Fenol, komposit $\mathrm{Ag} / \mathrm{ZnO}$, fotokatalis

\begin{abstract}
This research paper is about the photodegradation of phenol using composite $\mathrm{Ag} / \mathrm{ZnO}$ synthesized by coprecipitaion method. The study included synthesis of $\mathrm{Ag} / \mathrm{ZnO}$ composite, the determination of optimum condition of photodegradation $(\mathrm{pH}$, amount of photocatalyst and irradiation time), the effectivity of photodegradation, photodegradation rate and the reusability capacity of composite to degrade phenol. The result showed that coprecipitation method can produce $\mathrm{Ag} / \mathrm{ZnO}$ composite with the $\mathrm{Ag}$ percentage of 3.4\%. The synthesized $\mathrm{Ag} / \mathrm{ZnO}$ composite showed high photocatalytic activity. The optimum condition of phenol photodegradation were photocatalyst amount of $40 \mathrm{mg}, \mathrm{pH} 7$ and irradiation time of 8 hours. The effectivity of photocatalytic degradation of phenol at optimum conditions was $(82,88 \pm 0,41) \%$.
\end{abstract}

Keywords : $\mathrm{Ag} / \mathrm{ZnO}$ composite, phenol, photocatalyst

\section{PENDAHULUAN}

Pencemaran perairan oleh fenol dan turunananya menjadi isu penting yang berkembang dalam beberapa tahun terakhir. Menurut penelitian yang dilakukan Winarno et al. (2006), kandungan fenol di beberapa lokasi perairan di Teluk Jakarta sudah melebihi batas ambang yang dijinkan pemerintah, yaitu $0,002 \mathrm{mg} / \mathrm{L}$. Kandungan fenol pada air tanah dangkal pada jarak $1-375$ meter dari TPA Sampah Suwung Kelurahan Pedungan Denpasar sudah tergolong dalam tingkatan tercemar berat, yaitu kandungannya mencapai 17,39 mg/L (Arbain, dkk, 2008). Penelitian yang dilakukan pada beberapa Danau di Indonesia pada bulan Maret-Juli 2011 juga menunjukkan kadar fenol yang telah melebihi ambang batas, di mana kadarnya di Danau Tempe (Makasar) 0,009-0,03 $\mathrm{mg} / \mathrm{L}$, Danau Limboto (Makasar) 0,002-0,047 mg/L, Danau Singkarak (Sumatra Barat) 0,008$0,044 \mathrm{mg} / \mathrm{L}$, dan Danau Rawa Pening (Jawa Tengah) 4,14-6,11 mg/L) (Anonim, 2011).

Metode fotodegradasi menggunakan fotokatalis sangat potensial untuk menguraikan fenol menjadi senyawa-senyawa yang lebih sederhana dan kurang toksik. Dalam penelitian ini akan digunakan fotokatalis $\mathrm{ZnO}$ karena memiliki berbagai keunggulan antara lain memiliki band gap yang lebar yaitu 3,37 eV (Pearton et al., 2005, Kołodziejczak-Radzimska dan Jesionowski, 2014; Wang, 2015), cenderung murah dan memiliki 
aktivitas fotokatalitik tinggi (Sakthivel, et. al., 2003).

Kinerja fotokatalis $\mathrm{ZnO}$ dapat ditingkatkan dengan kombinasi $\mathrm{ZnO}$ dengan partikel logam mulia yang dikenal dengan komposit logam mulia/ZnO. Partikel logam mulia dapat meningkatkan kinerja fotokatalitik $\mathrm{ZnO}$ dengan menghambat rekombinasi dari pasangan electronhole karena rekombinasi yang cepat dari pasangan electron-hole akan menurunkan efisiensi katalitik. Hambatan Schottky (Schottky barrier) pada antarmuka logam-semikonduktor dapat memisahkan elektron fotoinduksi dan hole secara efektif karena logam mulia dapat berfungsi sebagai penyerap elektron (electron sinks), sehingga meningkatkan aktivitas fotokatalitiknya (Xu, et al., 2013; Divband, et al., 2013). Diantara semua logam mulia, perak mempunyai potensi yang sangat besar untuk meningkatkan aktivitas degradasi dari $\mathrm{ZnO}$ dan harganya paling murah (Simon, 2011).

Komposit $\mathrm{Ag} / \mathrm{ZnO}$ dapat dibuat dengan beberapa metode antara lain metode kopresipitasi, metode sol-gel, teknik induksi hibrid dan pemanasan laser, fotoreduksi, fotolisis impregnasi, pirolisis semprot nyala, dan pirolisis semprot ultrasonik (Benhebal, et al., 2012; Jazi, et al., 2012). Dalam penelitian ini sintesis komposit $\mathrm{Ag} / \mathrm{ZnO}$ dibuat dengan metode kopresipitasi karena metode ini mudah, sederhana dan ukuran partikel yang diperoleh lebih kecil dan seragam serta morfologi partikel lebih mudah dikontrol (Jazi, et. al., 2012).

Persentase $\mathrm{Ag}$ dalam komposit $\mathrm{Ag} / \mathrm{ZnO}$ secara signifikan mempengaruhi jumlah senyawa organik yang terfotodegradasi oleh komposit. Persentase fotodegradasi untuk MB, MO, dan Orange $\mathrm{G}$ oleh komposit $\mathrm{Ag} / \mathrm{ZnO}$ meningkat dengan bertambahnya kandungan $\mathrm{Ag}$ dalam komposit (Cheng, et al., 2013; Gao, et al., 2011; Amornpitoksuk, et al., 2012). Berdasarkan latar belakang di atas maka dalam penelitian ini dilakukan sintesis komposit $\mathrm{Ag} / \mathrm{ZnO}$ dengan metode kopresipitasi, selanjutnya komposit yang dihasilkan untuk mendegradasi fenol yang merupakan limbah yang sangat sukar didegradasi secara alami di alam.

\section{MATERI DAN METODE}

\section{Bahan}

Bahan-bahan kimia yang digunakan dalam penelitian ini adalah berkualitas pro analisis (p.a) yaitu : $\mathrm{AgNO}_{3}, \mathrm{Zn}\left(\mathrm{NO}_{3}\right)_{2} .6 \mathrm{H}_{2} \mathrm{O}, \mathrm{Na}_{2} \mathrm{CO}_{3}$, $\mathrm{C}_{6} \mathrm{H}_{5} \mathrm{OH}, \mathrm{NaOH}, \mathrm{HCl}, \mathrm{NH}_{4} \mathrm{OH}, \mathrm{KH}_{2} \mathrm{PO}_{4}, \mathrm{~K}_{2} \mathrm{HPO}_{4}$, 4-aminoantipirin, $\mathrm{K}_{4} \mathrm{Fe}(\mathrm{CN})_{6}$. Selain itu juga digunakan akuades, akuabides, dan kertas saring Whatman 42.

\section{Peralatan}

Peralatan yang digunakan dalam penelitian ini adalah: alat-alat gelas, timbangan analitik, $\mathrm{pH}$ meter, pengaduk magnetik, pemanas, oven, tanur, vacuum water jet pump, reaktor radiasi, plastik hitam, lampu Philips TUV 15 W / G15 T8, spektrofotometer UV-Vis 1800 Shimadzu, X-Ray Flourecense (XRF) merk PAN analytical Tipe Minipal 4, Scanning Electron Microscope (SEM) Merk FEI Type Inspect-S50 yang dilengkapi dengan EDX, dan X-Ray Diffraction (XRD).

\section{Cara Kerja \\ Sintesis komposit Ag/ $\mathrm{ZnO}$}

Metode sintesis yang digunakan adalah metode Jazi, et. al., 2012 dengan memodifikasi konsentrasi reaktan. Sebanyak $50 \mathrm{mmol} \mathrm{Zn}\left(\mathrm{NO}_{3}\right)_{2}$. $4 \mathrm{H}_{2} \mathrm{O}$ dan 1,57 mmol $\mathrm{AgNO}_{3}$ dilarutkan dengan akuabides hingga volumenya $50 \mathrm{~mL}$ dan dihomogenkan. Larutan dimasukkan ke dalam erlenmeyer $500 \mathrm{~mL}$ dan ditambahkan $125 \mathrm{~mL}$ larutan $\mathrm{Na}_{2} \mathrm{CO}_{3} 0,5 \mathrm{M}$ dengan cara penetesan melalui corong dengan kecepatan $2 \mathrm{~mL} /$ menit. Selama reaksi berlangsung diaduk dengan kuat pada suhu kamar dan terus diaduk selama 15 menit setelah reagen $\mathrm{Na}_{2} \mathrm{CO}_{3} 0,5 \mathrm{M}$ habis diteteskan. Endapan perak dan seng karbonat yang terbentuk dibiarkan semalam. Selanjutkan endapan dicuci sampai $\mathrm{pH}$ filtrat sama dengan $\mathrm{pH}$ akuabides dan kemudian disaring dengan kertas whatman 42 menggunakan penyaring vacuum. Selanjutnya endapan dikeringkan angin semalam. Endapan digerus kemudian diayak dengan ayakan 200 mesh. Serbuk yang lolos 200 mesh ini kemudian di oven suhu $110^{\circ} \mathrm{C}$ selama 2 jam. Setelah kering endapan dikalsinasi pada suhu $400^{\circ} \mathrm{C}$ selama 4 jam. Komposit $\mathrm{Ag} / \mathrm{ZnO}$ yang terbentuk dari hasil kalsinasi didinginkan kemudian disimpan dalam desikator untuk penelitian lebih lanjut. 


\section{Penentuan jumlah komposit Ag/ZnO optimum dalam fotodegradasi}

Enam buah gelas beker $250 \mathrm{~mL}$ diisi 100 $\mathrm{mL}$ larutan fenol $50 \mathrm{ppm}$ dan ditambahkan komposit Ag/ZnO sebanyak 20, 30, 40, 50, 60 dan $70 \mathrm{mg}$. Gelas beker yang telah berisi campuran fenol dan komposit dimasukkan ke reaktor. Selanjutnya campuran diradiasi dengan lampu UV selama 5 jam, sambil diaduk dengan pengaduk magnetik. Setelah proses radiasi, suspensi disaring dan filtrat diukur absorbansinya dengan spektrofotometer UV-Vis pada panjang gelombang maksimum fenol.

\section{Penentuan pH optimum fotodegradasi}

Tujuh buah gelas beker $250 \mathrm{~mL}$ diisi 100 $\mathrm{mL}$ larutan fenol $50 \mathrm{ppm}$ dan ditambahkan komposit $\mathrm{Ag} / \mathrm{ZnO}$ pada jumlah optimumnya. Keenam larutan tersebut diatur pHnya dari 4, 5, 6, $7,8,10$, dan 11. Kemudian gelas beker yang telah berisi campuran fenol dan komposit diradiasi dengan sinar UV selama 5 jam, sambil diaduk dengan pengaduk magnetik. Setelah proses radiasi, filtrat dari masing-masing perlakuan diukur absorbansinya dengan spektrofotometer UV-Vis pada panjang gelombang maksimum fenol.

\section{Penentuan waktu optimum fotodegradasi}

Delapan buah gelas beker $250 \mathrm{~mL}$ diisi $100 \mathrm{~mL}$ larutan fenol $50 \mathrm{ppm}$, ditambahkan komposit $\mathrm{Ag} / \mathrm{ZnO}$ pada jumlah optimumnya, kemudian pHnya diatur pada $\mathrm{pH}$ optimum yang diperoleh pada prosedur di sebelumnya. Selanjutnya gelas yang telah berisi campuran fenol dan komposit diradiasi dengan sinar UV masingmasing selama 1, 2, 3, 4, 5, 6, 7 dan 8 jam, sambil diaduk dengan pengaduk magnetik. Kemudian filtrat masing-masing perlakuan diukur absorbansinya dengan spektrofotometer UV-Vis pada panjang gelombang maksimum fenol.

\section{Penentuan efektivitas proses fotodegradasi}

Tiga buah gelas beker $100 \mathrm{~mL}$ diisi $50 \mathrm{~mL}$ larutan fenol $50 \mathrm{ppm}$, ditambahkan komposit $\mathrm{Ag} / \mathrm{ZnO}$ pada jumlah optimumnya, kemudian pHnya diatur pada $\mathrm{pH}$ optimum. Selanjutnya gelas beker yang telah berisi campuran fenol dan komposit diradiasi dengan sinar UV selama waktu optimum sambil diaduk dengan pengaduk magnetik. Setelah proses radiasi, filtrat masingmasing perlakuan diukur absorbansinya dengan spektrofotometer UV-Vis pada panjang gelombang maksimum fenol. Absorbansi yang diperoleh kemudian dimasukkan ke dalam persamaan regresi linear larutan fenol, sehingga diperoleh konsentrasi fenol. Efektivitas fotodegradasi fenol dengan bahan fotokatalis komposit $\mathrm{Ag} / \mathrm{ZnO}$ dan sinar UV dapat ditentukan dengan perhitungan persentase degradasi (\% D).

\section{Penentuan efektivitas proses fotodegradasi}

Tiga buah gelas beker $100 \mathrm{~mL}$ diisi $50 \mathrm{~mL}$ larutan fenol $50 \mathrm{ppm}$, ditambahkan komposit $\mathrm{Ag} / \mathrm{ZnO}$ pada jumlah optimumnya, kemudian pHnya diatur pada $\mathrm{pH}$ optimum. Selanjutnya gelas beker yang telah berisi campuran fenol dan komposit diradiasi dengan sinar UV selama waktu optimum sambil diaduk dengan pengaduk magnetik. Setelah proses radiasi, filtrat masingmasing perlakuan diukur absorbansinya dengan spektrofotometer UV-Vis pada panjang gelombang maksimum fenol. Absorbansi yang diperoleh kemudian dimasukkan ke dalam persamaan regresi linear larutan fenol, sehingga diperoleh konsentrasi fenol. Efektivitas fotodegradasi fenol dengan bahan fotokatalis komposit $\mathrm{Ag} / \mathrm{ZnO}$ dan sinar UV dapat ditentukan dengan perhitungan persentase degradasi (\% D).

Analisis Fenol dengan Spektrofotometer UV-Vis.

Sebanyak $50 \mathrm{~mL}$ filtrat hasil fotodegradasi dimasukkan ke dalam gelas beker. Filtrat ditambahkan 2,5 mL larutan $\mathrm{NH}_{4} \mathrm{OH} 0,5 \mathrm{~N}$ dan pHnya diatur menjadi $7,9 \pm 0,1$ dengan penambahan larutan penyangga fosfat. Selajutnya ditambahkan1 $\mathrm{mL}$ larutan aminoantipirin sambil diaduk, ditambahkan $1 \mathrm{~mL}$ larutan kalium ferisianida sambil diaduk, didiamkan sampai terbentuk warna merah stabil. Larutan dimasukkan ke dalam kuvet pada alat spektrofotometer, dan dibaca absorbansi pada panjang gelombang maksimum fenol.

\section{HASIL DAN PEMBAHASAN}

\section{Komposit Ag/ZnO}

Reaksi yang terjadi pada sintesis komposit $\mathrm{Ag} / \mathrm{ZnO}$ dengan metode kopresipitasi adalah sebagai berikut (Jazi, et al., 2012) :

$$
\begin{aligned}
& 2 \mathrm{AgNO}_{3}+\mathrm{Na}_{2} \mathrm{CO}_{3} \rightarrow \mathrm{Ag}_{2} \mathrm{CO}_{3}+2 \mathrm{NaNO}_{3} \\
& \mathrm{Zn}\left(\mathrm{NO}_{3}\right)_{2}+\mathrm{Na}_{2} \mathrm{CO}_{3} \rightarrow \mathrm{ZnCO}_{3}+2 \mathrm{NaNO}_{3}
\end{aligned}
$$

Endapan perak karbonat dan seng karbonat yang terbentuk dikeringkan dalam oven suhu 
$110^{\circ} \mathrm{C}$, selanjutnya endapan dikalsinasi pada suhu $400^{\circ} \mathrm{C}$ selama 4 jam untuk merubah perak karbonat dan seng karbonat menjadi komposit $\mathrm{Ag} / \mathrm{ZnO}$, dengan reaksi berikut (Jazi, et. al., 2012):

$\mathrm{Ag}_{2} \mathrm{CO}_{3} \rightarrow \mathrm{Ag}_{2} \mathrm{O}+\mathrm{CO}_{2}$

$\mathrm{ZnCO}_{3} \rightarrow \mathrm{ZnO}+\mathrm{CO}_{2}$

$\mathrm{Ag}_{2} \mathrm{O} \rightarrow \mathrm{Ag}+1 / 2 \mathrm{O}_{2}$

Berdasarkan pola difraksi sinar X (XRD), $\mathrm{ZnO}$ hasil sintesis mempunyai struktur Wurtzite heksagonal yang ditunjukkan oleh adanya puncakpuncak khas pada $2 \Theta 31,09^{\circ} ; 33,76^{\circ}$ dan $36,60^{\circ}$. Puncak-puncak difraksi juga menunjukkan adanya Ag dengan struktur face centre cubic (fcc) pada $2 \Theta$ $37,84^{\circ} ; 43,76^{\circ}$ dan $63,88^{\circ}$. Data analisis semikuantitatif dengan XRF menunjukkan persentase $\mathrm{Ag}$ dalam komposit $\mathrm{Ag} / \mathrm{ZnO}$ sebesar 3,4 \%. Sementara karakterisasi dengan SEM menunjukkan bahwa komposit $\mathrm{Ag} / \mathrm{ZnO}$ berbentuk bulat dan bergerombol seperti diperlihatkan pada Gambar 1.

\section{Jumlah komposit Ag-ZnO optimum dalam fotodegradasi fenol}

Penentuan jumlah komposit $\mathrm{Ag} / \mathrm{ZnO}$ optimum dalam proses fotodegradasi fenol dilakukan dengan memvariasikan jumlah komposit $\mathrm{Ag} / \mathrm{ZnO}$, yaitu 20, 30, 40, 50, 60 dan $70 \mathrm{mg}$. Untuk mengetahui jumlah komposit $\mathrm{Ag} / \mathrm{ZnO}$ optimum dalam proses fotodegradasi fenol dilakukan dengan membuat kurva hubungan antara jumlah

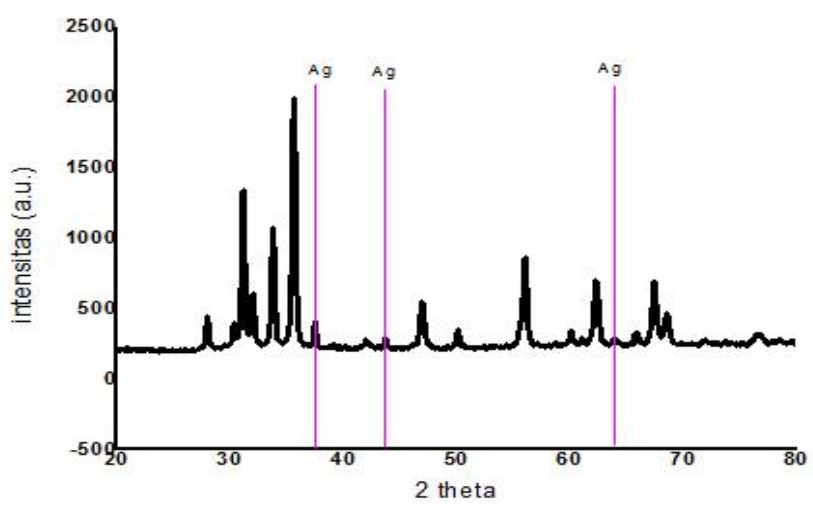

komposit $\mathrm{Ag} / \mathrm{ZnO}$ sebagai sumbu $\mathrm{x}$ dengan persentasi fotodegradasi sebagai sumbu y. Kurva yang diperoleh pada penelitian ini disajikan pada Gambar 2.

Pada awal kurva pada Gambar 2 dapat dilihat bahwa penambahan jumlah komposit $\mathrm{Ag} / \mathrm{ZnO}$ yang semakin banyak, semakin meningkatkan persentase fenol yang terdegradasi, dimana persentase fotodegradasi maksimum dicapai pada penambahan komposit $50 \mathrm{mg}$. Namun selanjutnya penambahan jumlah komposit $\mathrm{Ag} / \mathrm{ZnO}$ yang lebih besar dari $50 \mathrm{mg}$ justru menurunkan persentase fotodegradasi fenol. Hal ini karena penambahan jumlah komposit yang berlebihan, sebagian komposit hanya menyebabkan kekeruhan pada larutan yang menghalangi sinar UV masuk lebih jauh ke larutan sehingga mengurangi jumlah elektron $\left(\mathrm{e}_{\mathrm{cb}}^{-}\right)$dan hole $\left(\mathrm{h}^{+}{ }_{\mathrm{vb}}\right)$ yang dihasilkan oleh fotokatalis komposit dan akibatnya jumlah fenol yang terdegradasi juga tidak maksimal. Dengan demikian jumlah komposit $\mathrm{Ag} / \mathrm{ZnO}$ sebesar $50 \mathrm{mg}$ adalah jumlah optimum yang dapat ditambahkan untuk mendegradasi $100 \mathrm{~mL}$ larutan fenol $50 \mathrm{ppm}$. Sampai batas maksimal jumlah fotokatalis $50 \mathrm{mg}$ ini, persentase degradasi (\%D) fenol yang terdegradasi semakin meningkat seiring dengan semakin meningkatnya jumlah permukaan fotokatalis yang menyediakan radikal anion superoksida dan radikal hidroksil yang dapat mendegrasi fenol.

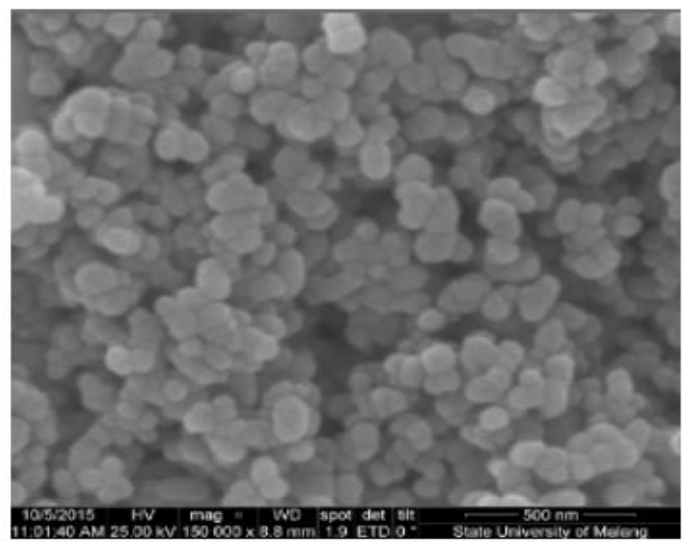

Gambar 1. Pola difraksi sinar $\mathrm{X}$ dan foto SEM komposit Ag/ZnO 


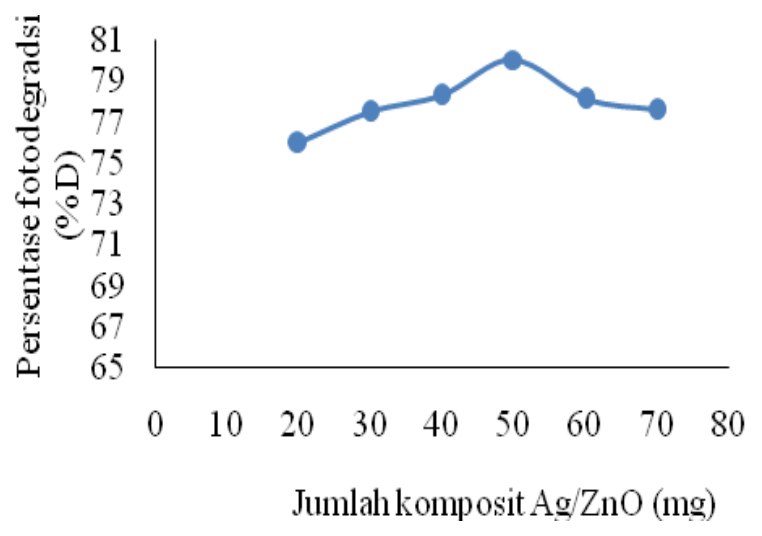

Gambar 2. Kurva hubungan antara jumlah komposit $\mathrm{Ag} / \mathrm{ZnO}(\mathrm{mg})$ terhadap persentase fenol yang terdegradasi (\%D)

Pada proses fotokatalisis, ketika permukaan fotokatalis dikenai sinar ultraviolet (UV) dengan energi foton yang sama atau lebih tinggi dari energi celah pitanya, elektron yang ada pada pita velensi tereksitasi ke pita konduksi sehingga meninggalkan lubang pada pita valensi. Elektron fotogenarasi pada pita konduksi $\left(\mathrm{e}_{\mathrm{cb}}^{-}\right)$ini bereaksi dengan oksigen menghasilkan radikal anion superoksida $\left(\cdot \mathrm{O}_{2}^{-}\right)$sedangkan lubang pada pita valensi $\left(\mathrm{h}^{+}{ }_{\mathrm{vb}}\right)$ bereaksi dengan molekul air menghasilkan radikal hidroksil $(\cdot \mathrm{OH})$. Kedua radikal inilah yang berperan untuk mendegradasi fenol. Namun pada proses fotokalisis sebagian dari elektron pada pita konduksi dan lubang pada pita valensi bergabung kembali sebelum sempat bereaksi menghasilkan radikal anion superoksida ataupun radikal hidroksil. Peristiwa rekombinasi ini tentunya mengurangi aktivitas fotokatalitik dari fotokatalis (Lachheb, et al., 2002, Han et al., 2013; Sinde et al., 2011). Adanya nanopartikel Ag (Ag NPs) dalam komposit $\mathrm{Ag} / \mathrm{ZnO}$ meningkatkan segregasi muatan dan mencegah rekombinasi dari pasangan electron-hole ini, dimana Ag NPs ini bertindak sebagai electron sinks yang memerangkap elektron dari pita konduksi sehingga mencegah rekombinasi elektron dengan lubang (Divband et al., 2013; Trandafilovic et al., 2014; Liu et al., 2015). Dengan demikian pembentukan radikal anion superoksida ataupun radikal hidroksil semakin optimal dan persentase fenol yang terdegradasi juga semakin banyak.

\section{Pengaruh pH terhadap fotodegradasi fenol}

$\mathrm{pH}$ mempunyai pengaruh yang signifikan pada kecepatan fotodegradasi fenol dalam proses fotokatalitik. Pengaruh $\mathrm{pH}$ diteliti dalam rentang $\mathrm{pH}$ 4-11 yang diatur dengan menambahkan sejumlah kecil $\mathrm{HCl}$ atau $\mathrm{NaOH}$ sebelum radiasi. Berdasarkan hasil penelitian yang diperlihatkan pada Gambar 3, persentase fotodegradasi fenol meningkat dari $\mathrm{pH} 4$ sampai 7 dan setelah itu mengalami penurunan.

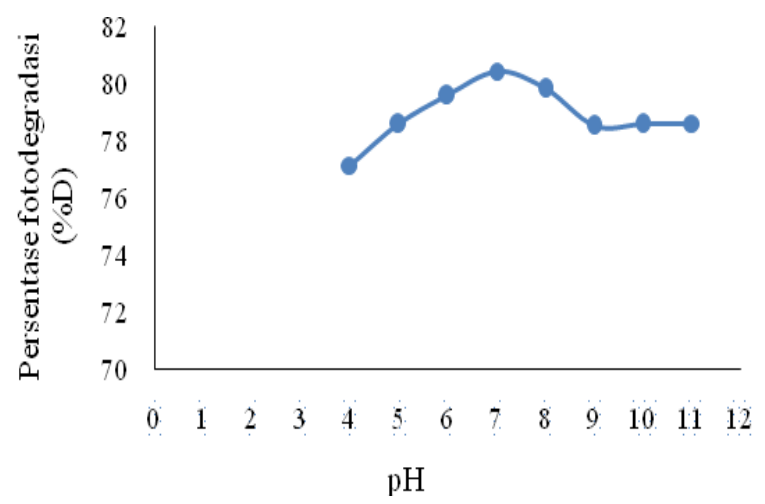

Gambar 3. Kurva hubungan antara $\mathrm{pH}$ larutan terhadap persentase fotodegradasi fenol

Pengaruh $\mathrm{pH}$ pada fotodegradasi fenol oleh semikonduktor oksida $\mathrm{ZnO}$ berhubungan dengan $\mathrm{pH}$ zero point charge (pHzpc) $\mathrm{ZnO}$ dan pKa fenol. Nilai $\mathrm{pH}$ dari permukaan $\mathrm{ZnO}$ yang tidak bermuatan (pHzpc $\mathrm{ZnO}$ ) adalah 9,3 sedangkan pKa fenol adalah 9,9 (Sin et al., 2013). Pada $\mathrm{pH}<\mathrm{pHzpc}$, permukaan $\mathrm{ZnO}$ bermuatan positif sedangkan $\mathrm{pH}>\mathrm{pHzpc}$ permukaan $\mathrm{ZnO}$ bermuatan negatif.

Dalam kondisi asam, efisiensi fotodegradasi fenol oleh fotokatalis komposit $\mathrm{Ag} / \mathrm{ZnO}$ rendah. Dalam kondisi asam, permukaan komposit $\mathrm{Ag} / \mathrm{ZnO}$ bermuatan positif, sementara fenol mengalami protonasi sehingga akan menghalangi adsorpsi fenol pada permukaan komposit. Terhalangnya adsorpsi fenol pada permukaan komposit, menyebabkan degradasi fenol oleh komposit $\mathrm{Ag} / \mathrm{ZnO}$ juga terhalangi sehingga persentase fotodegradasi rendah (Meshram, et al., 2011). Di samping itu pada kondisi asam kuat, $\mathrm{ZnO}$ juga mudah mengalami disosiasi menghasilkan ion $\mathrm{Zn}^{2+}$, sedangkan dalam kondisi basa kuat terdisosiasi menghasilkan $\mathrm{Zn}(\mathrm{OH})_{4}{ }^{2-}$ sehingga mengurangi efisiensi katalitik 
dari komposit pada kondisi tersebut. Reaksi disosiasi $\mathrm{ZnO}$ dalam suasana asam kuat dan basa kuat adalah sebagai berikut (Sin, et al., 2013):

$$
\begin{aligned}
& \mathrm{ZnO}+2 \mathrm{H}^{+} \rightarrow \mathrm{Zn}^{2+}+\mathrm{H}_{2} \mathrm{O}(\text { kondisi asam }) \\
& \mathrm{ZnO}+\mathrm{H}_{2} \mathrm{O}+2 \mathrm{OH}^{-} \rightarrow \mathrm{Zn}(\mathrm{OH})_{4}^{2-}(\text { kondisibasa })
\end{aligned}
$$

Efisiensi fotodegradasi fenol oleh komposit $\mathrm{Ag} / \mathrm{ZnO}$ juga dipengaruhi oleh ion disosiasi yang berasal dari zat pengatur $\mathrm{pH}$ yaitu $\mathrm{HCl}$ dan $\mathrm{NaOH}$. Ion disosiasi dari pengatur $\mathrm{pH}$ ini dapat berkompetisi dengan molekul fenol pada permukaan $\mathrm{Ag} / \mathrm{ZnO}$. Pada kondisi asam, ion $\mathrm{Cl}^{-}$ dari $\mathrm{HCl}$ mungkin teradsorpsi pada permukaan $\mathrm{Ag} / \mathrm{ZnO}$ sehingga mengurangi jumlah fenol yang dapat terdegradasi. Di sisi lain, pada kondisi basa, terjadi adsorpsi kompetitif fenol dan ion dari $\mathrm{NaOH}$ pada permukaan $\mathrm{Ag} / \mathrm{ZnO}$ sehingga menurunkan aktivitas fotokatalitik $\mathrm{ZnO}$ terhadap fenol. Selain itu, pada $\mathrm{pH}$ tinggi $(\mathrm{pH}>\mathrm{pHzpc}$ dari $\mathrm{ZnO}$ ), permukaan komposit $\mathrm{Ag} / \mathrm{ZnO}$ bermuatan negatif sehingga anion fenolat $\left(\mathrm{C}_{6} \mathrm{H}_{5} \mathrm{O}^{-}\right)$ditolak oleh permukaan fotokatalis dan menghalangi fotodegradasi fenol pada permukaan komposit $\mathrm{Ag} / \mathrm{ZnO}$ (Sin, et al., 2013). Pada pH sekitar 6-8, hanya sedikit menambahkan $\mathrm{HCl}$ atau $\mathrm{NaOH}$ untuk mengatur $\mathrm{pH}$ karena larutan fenol yang digunakan mempunyai $\mathrm{pH}$ sekitar 7 , sehingga daya tarik elektrostratik antara muatan positif $\mathrm{ZnO}$ dengan anion fenolat tidak dipengaruhi oleh ion disosiasi zat pengatur $\mathrm{pH}$ dan menyebabkan efisiensi degradasi fotokatalitik fenol oleh komposit $\mathrm{Ag} / \mathrm{ZnO}$ maksimal. Persentase fotodegradasi maksimum terjadi pada $\mathrm{pH} 7$, sehingga $\mathrm{pH} 7$ dipakai sebagai $\mathrm{pH}$ kondisi optimum fotodegradasi fenol oleh komposit $\mathrm{Ag} / \mathrm{ZnO}$.

\section{Pengaruh waktu terhadap fotodegradasi fenol}

Untuk mengetahui pengaruh waktu reaksi terhadap jumlah fenol yang terdegradasi dilakukan dengan memvariasikan waktu reaksi, yaitu 1, 2, 3, 4, 5, 6, 7 dan 8 jam. Dari data yang diperoleh dibuat kurva dengan menghubungkan waktu reaksi larutan fenol dengan persentase fotodegradasi (\%) seperti yang ditunjukan pada Gambar 4.

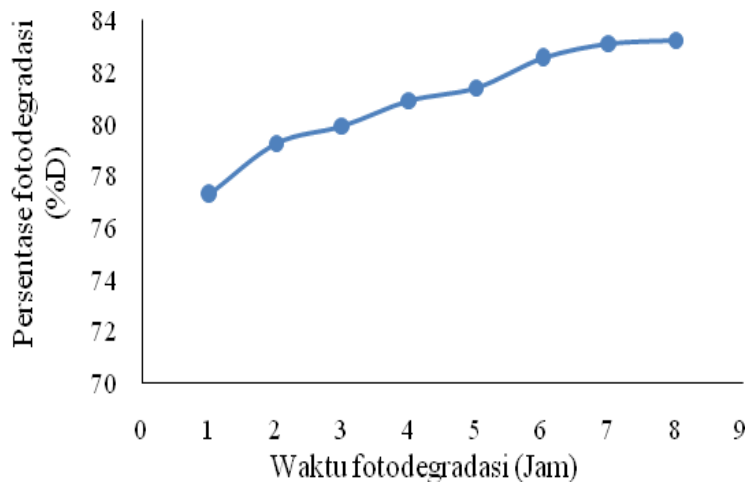

Gambar 4. Kurva hubungan antara waktu fotodegradasi (jam) terhadap persentase fotodegradasi fenol (\%D)

Kurva diatas menunjukan bahwa persentase fotodegradasi (\%D) fenol semakin meningkat seiring dengan semakin lamanya waktu fotodegradasi. Semakin lama komposit $\mathrm{Ag} / \mathrm{ZnO}$ disinari sinar ultraviolet, semakin banyak jumlah radikal anion superoksida $\left(\cdot \mathrm{O}_{2}^{-}\right)$dan hidroksil $(\bullet \mathrm{OH})$ yang terbentuk sehingga semakin banyak juga jumlah fenol yang mengalami fotodegradasi. Dalam penelitian ini, waktu fotodegradasi sampai 8 jam, jumlah fenol yang terdegradasi masih meningkat namun peningkatan lebih kecil dibandingkan waktu sebelumnya. Pada waktu fotodegradasi 8 jam, komposit $\mathrm{Ag} / \mathrm{ZnO}$ mampu mendegradasi fenol sebesar $83,22 \%$.

\section{Laju Fotodegradasi Fenol}

Penentuan konstanta laju fotodegradasi fenol menggunakan data pengaruh waktu reaksi terhadap jumlah fenol yang terdegradasi. Data yang diperoleh dibuat kurva hubungan $\ln [\mathrm{C}]$ vs $\mathrm{t}$ (waktu), dimana harga slope dari kurva merupakan tetapan laju reaksi (k). Kurva hubungan $\ln [\mathrm{C}]$ vs t (waktu) diperlihatkan pada Gambar 5.

Persamaan laju fotodegradasi fenol dengan komposit $\mathrm{Ag} / \mathrm{ZnO}$ adalah $\mathrm{y}=-0.0428 \mathrm{x}+2,4422$. Nilai slope dari persamaan laju merupakan negatif dari konstanta laju fotodegradasi (-k). Dengan demikian, nilai tetapan laju fotodegradasi fenol dengan fotokatalis komposit $\mathrm{Ag} / \mathrm{ZnO}$ adalah $0,0428 \mathrm{jam}^{-1}$. 


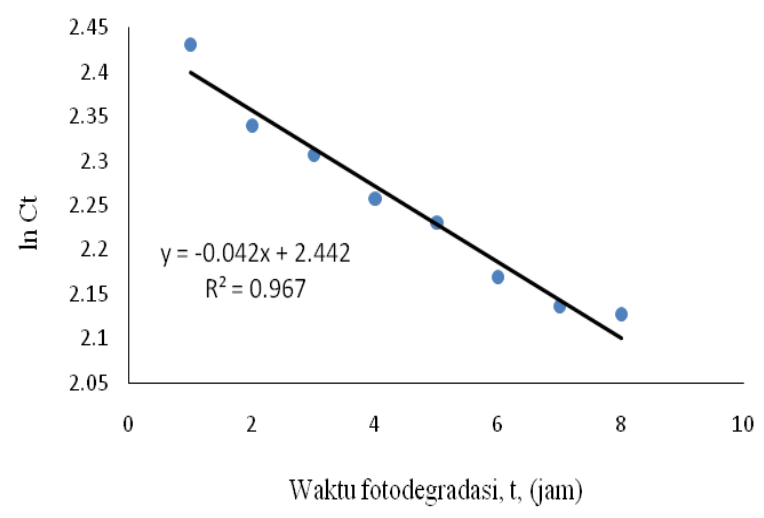

Gambar 5. Kurva laju fotodegradasi fenol dengan fotokatalis komposit $\mathrm{Ag} / \mathrm{ZnO}$

\section{Efektivitas Fotodegradasi}

Efektivitas proses fotodegradasi fenol dilakukan dengan pengulangan sebanyak 3 kali. Fenol diberi perlakuan pada kondisi optimum yang diperoleh dari hasil penelitian sebelumnya dengan menambahkan komposit Ag/ZnO sebanyak $50 \mathrm{mg}$, diatur pada $\mathrm{pH} 7$ dan diradiasi dengan sinar UV selama 8 jam. Efektivitas fotodegradasi fenol rata-rata dengan fotokatalis komposit $\mathrm{Ag} / \mathrm{ZnO}$ sebesar $(82,88 \pm 0,41) \%$. Dari nilai persentase fotodegradasi ini, fotokatalis komposit $\mathrm{Ag} / \mathrm{ZnO}$ ini lebih efektif dalam mendegradasi fenol $50 \mathrm{ppm}$ dibandingkan dengan fotokatalis $\mathrm{ZnO}$ yang diperoleh dari penelitian sebelumnya yang dilakukan oleh Permata, dkk. (2016) yaitu hanya sebesar 63,53 \pm 49$) \%$. Adanya Ag NPs dalam komposit $\mathrm{Ag} / \mathrm{ZnO}$ terbukti mampu meningkatkan efektivitas fotodegradasi dari fotokatalis komposit $\mathrm{Ag} / \mathrm{ZnO}$ dibandingan dengan fotokatalis $\mathrm{ZnO}$.

\section{SIMPULAN DAN SARAN}

\section{Simpulan}

Metode presipitasi dapat menghasilkan komposit $\mathrm{Ag} / \mathrm{ZnO}$ yang berbentuk bulat bergerombol (clustered spherical shape) dengan persentase Ag dalam komposit sebesar 3,4\%. Hasil difraksi sinar $\mathrm{X}$ menunjukan $\mathrm{ZnO}$ dengan struktur Wurtzite heksagonal dan Ag dengan struktur face center cubic (fcc). Komposit $\mathrm{Ag} / \mathrm{ZnO}$ yang dihasilkan mempunyai aktivitas fotokatalitik yang tinggi. Kondisi optimum proses fotodegradasi fenol dengan komposit $\mathrm{Ag} / \mathrm{ZnO}$ yaitu dengan menggunakan komposit $\mathrm{Ag} / \mathrm{ZnO}$ sebanyak $50 \mathrm{mg}$,
$\mathrm{pH}$ larutan fenol 7 dan diradiasi dengan sinar UV selama 8 jam. Laju fotodegradasi fenol dengan fotokatalis komposit $\mathrm{Ag} / \mathrm{ZnO}$ sebesar 0,0428 $\mathrm{jam}^{-1}$ dan efektivitas fotodegradasinyapada kondisi optimum sebesar $(82,88 \pm 0,41) \%$.

\section{Saran}

Dari penggunaan di lapangan limbah fenol seringkali bercampur dengan polutan yang lain, oleh karena itu perlu dikaji bagaimana pengaruh polutan lain ini terhadap kemampuan fotodegradasi $\mathrm{Ag} / \mathrm{ZnO}$ terhadap fenol.

\section{UCAPAN TERIMA KASIH}

Terima kasih kepada LPPM Universitas Udayana yang telah memberikan dana penelitian melalui Penelitian Produk Terapan dana RISTEKDIKTI tahun 2016 dengan kontrak nomor: 486.65/UN14.2/PNL.01.03.00/2016.

\section{DAFTAR PUSTAKA}

Amornpitoksuk, P., Suwanboon, S., Sangkanu, S., Sukhoom, A., Muensit, N., Baltrusaitis, J., 2012, Synthesis, characterization, photocatalytic and antibacterial activities of Agdoped $\mathrm{ZnO}$ powders modified with a diblock copolymer, Powder Technology, 219: $158-164$

Anonim, 2011, Laporan Pemantauan Kualitas Air Danau di Indonesia, PUSARPEDAL Kementerian Lingkungan Hidup, Serpong

Arbain, NK Mardana, IB Sudana, 2008, Pengaruh Air Lindi Tempat Pembuangan Akhir Sampah Suwung terhadap Kualitas Air Tanah Dangkal di Sekitarnya di Kelurahan Pedungan Kota Denpasar, Ecotrophic, 3 (2): $55-60$

Cheng, Y., An, L., Lan, J., Gao, F., Tan, R., Li, X., Wang, G., 2013, Facile synthesis of pompon-like $\mathrm{ZnO}-\mathrm{Ag}$ nanocomposites and their enhanced photocatalytic performance, Materials Research Bulletin, 48: 4287-4293

Divband, B., Khatamian, M., Eslamian, G. R. K. \& Darbandi, M., 2013, Synthesis of Ag/ZnO nanostructures by different methods and 
investigation of their photocatalytic efficiency for 4-nitrophenol degradation. Appl. Surf. Sci.,284: 80-86

Gao, S., Jia. X., Yang, S., Li, Z., Jiang, K., 2011, Hierarchical $\mathrm{Ag} / \mathrm{ZnO}$ micro/nanostructure: Green synthesis and enhanced photocatalytic performance, Journal of Solid State Chemistry, 184: 764-769

Jazi, F. S., Parvina, N., Rabiei, M., Tahriri, M., Shabestari, Z. M., and Azadmehr, A. R., 2012, The effect of the synthesis route on the grain size and morphology of $\mathrm{ZnO} / \mathrm{Ag}$ Nanocomposite, Journal of Ceramic Processing Research, 13(5): 523-526

Kołodziejczak-Radzimska, A. \& Jesionowski, T., 2014, Zinc Oxide-From Synthesis to Application: A Review. Materials (Basel), 7: 2833-2881

Meshram, S., Limaye, R., Ghodke, S., Nigam, S., Sonawane, S., Chikate, R., 2011, Continuous flow photocatalytic reactor using $\mathrm{ZnO}$-bentonite nanocomposite for degradation of phenol, Chemical Engineering Journal, 172: 1008-1015

Nezamzadeh-Ejhieh, A., Khorsandi, S., 2014, Photocatalytic degradation of 4nitrophenol with $\mathrm{ZnO}$ supported nanoclinoptilolite zeolite, Journal of Industrial and Engineering Chemistry, 20: 937-946

Pearton, S. J., Norton, D. P. \& Ip, K., 2005, Recent progress in processing and properties of $\mathrm{ZnO}$, Progress in Materials Science, 50: 293-340

Permata, D.S., Diantariani, N.P, Widihati, I.A.G., 2016, Degradasi fotokatalitik fenol menggunakan fotokatalis $\mathrm{ZnO}$ dan sinar UV, Jurnal Kimia Universitas Udayana, 10 (2): 263-269

Sakthivel S., B. Neppolian, M. V. Shankar, B. Arabindoo, M. Palanichamy, and M. Murugesan. 2003. Solar Photocatalytic Degradation of Azo Dye: Comparison of Photocatalytic Efficiency of $\mathrm{ZnO}$ and TiO2. Solar Energy Material and Solar Cells., 77: $65-82$

Simon, et. al., 2011, Plasma-assisted synthesis of $\mathrm{Ag} / \mathrm{ZnO}$ nanocomposites: First example of photo-induced $\mathrm{H}_{2}$ production and sensing, International Journal of Hydrogen Energy, 36: 15527-15537

Sin, J.C, Lam, S.M., Lee, K.T., Mohamed, A.R., 2013, Preparation and photocatalytic properties of visible light-driven samarium-doped $\mathrm{ZnO}$ nanorods, Ceramics International, 39: 5833-5843

Winarno, E. K., Andayani, W., and Sumartono, A., 2006, Distribution of Surfactant and Phenol in Coastal Waters of Jakarta Gulf, Indo. J. Chem., 6 (3): 251 - 255

Wang, Z. L., 2015, Splendid One-Dimensional Nanostructures of Zinc Oxide: A New Nanomaterial Family for Nanotechnology, ACS Nano, 2: 1987-1992

Xu, F., Yuan, Y., Wu, D., Zhao, M., Gao, Z., Jiang, K., 2013, Synthesis of $\mathrm{ZnO} / \mathrm{Ag} / \mathrm{graphene}$ composite and its enhanced photocatalytic efficiency. Mater. Res. Bull., 48: 2066-2070 